\title{
MAKINE OLARAK ANDY WARHOL
}

\author{
Yrd. Doç. Dr. Fatih ÖZDEMIR ${ }^{1}$, Okutman Binnaz KOCA ${ }^{2}$
}

\begin{abstract}
ÖZET
Kapitalizm, oluşturduğu pazara her sınıftan insanı katma amacıyla, bütün sınıfsal farkları aşarak popüler kültür adında ortak bir yaşam biçimi, ortak bir kültür sunmuştur. Andy Warhol, 1960'lı y1llarda ortaya çıkan pop sanatla popüler toplumun içinde yığınlar halinde bulunan tüketim metalarını kendine özgü üslubuyla sanata dönüştürmüştür.

Warhol, tüketim toplumunu oluşturan insanların üzerinde bask1, zorlama uygulamadan birbirine benzeyen tek tip insan modeli oluşturacağını görüp bu tüketim toplumuna makine olarak katılmak istemiştir. Tüketim metalarını üreten bir makine gibi, birbirinin aynısı, istediği kadar çoğaltabileceği, yorulmadan sürekli çalışabileceği bir makine... Kendi kişiliğini ve duygusunu katmadan derinliği olmayan sıradan nesneleri aktarırken kendisi de yüzeyselleşmiş olur. İmge üzerinde düşünülmeye gerek kalmaz. Serigrafi tekniğini kullanarak hedeflediği seri üretim mantığına ulaşmıştır ve ürettiği şeylerin birbirine benzemesini sağlamıştır. Konusu bazen çorba konserveleri bazen de ölüm resimleri olmuştur. Onun resimlerinde tüketim ürünleri ve sıradan nesneler gibi şiddet ve ölüm de gündelik bir nesneye dönüşür.
\end{abstract}

Anahtar Kelimeler: Warhol, Popart, Tüketim toplumu, Makine

\footnotetext{
${ }^{1}$ İnönü üniversitesi Güzel San. ve Tas. Fak. Öğretim Üyesi mfatihozdemir@gmail.com

${ }^{2}$ İnönü Üniversitesi Eğitim Fak. Resim-iş eğitimi bölümü, Malatya kocabinnaz@gmail.com
} 


\title{
ANDY WARHOL AS A MACHINE
}

\begin{abstract}
The capitalism goes beyond/crosses all of the class differences and offers a common life style, a common culture, called popular culture with the aim of including the people from all the classes in the market he formed. Andy Warhol transformed the consumption goods that exist in bulks in the community into the art with his distinctive style with the pop art that emerged in the 1960s.

Warhol considered the formation of standardized human model that resemble each other without pressure, force on the people constituting the consumption society and wanted to join this consumption society as the machine. Like a machine producing the consumption goods, a machine that is alike the others, that increases as it wishes, works continually and tirelessly... He would get superficial while conveying the facile ordinary subjects without adding his own personality and feeling. It is not necessary to think over the image. He reached the targeted mass production logic by using the screen printing technique and made the things he produced resemble the each other. His subjects were sometimes the canning soup and were sometimes the death paintings. In his paintings, like the consumption goods and ordinary objects, the violence and death turn into a casual object.
\end{abstract}

Keywords: Warhol, Popart, Consumer Society, Machine. 


\section{GíRiş}

Düşünceler dünyasının içinden doğan ortak bilinç, nesnel gerçekliğin öngörüleriyle yüklüdür. Bu öngörüler modern algının tüm gereksinimleri etrafında olgunlaşmaktadır. İnsanoğlunun kültürel konseptine dâhil olan bu algı, herhangi bir ideolojik söylemin söylem biçimi değildir. Çünkü özne, modernitenin ortak ruh halinden doğan bütünsel ihtiyaçlara teslim edilen görünürlüğe sahiptir. Modern çağın düşünce potansiyelleri bireysel düşünce modelleri üzerinden ortak bir algının benzeşmesi doğallı̆̆ını yansıtmaktadır.

\section{ANDY WARHOL: HERKES BİRBİIINE BENZIYYOR}

\section{Popart ve Andy Warhol}

Sanat eleştirmeni Lawrence Alloway tarafindan isimlendirilen pop, verdiği ses ile "sönen havanın gürültüsüdür, tıpkı bir balonunki gibi" (Danto 162)

Pop sözcüğ̈̈, sanat etkinliklerinde geniş bir alanı kapsar. Bu sayısız etkinliklerin paylaştığı ortak yol kitle iletişim imgelerine dayanmaları ve bazen de aynı yaratma sürecinden geçmeleridir. Bu yeni akım için başka pek çok isim önerilmiştir. Bunlardan 'New Vulgarianizm' (yeni bayağılık, adilik), eleştirmenlerin duyduğu tiksintiyi ifade ederken 'yeni gerçekçilik' ve 'yeni dadacıllk' isimleri ise bu akımların sanat tarihiyle olan bağlarını vurgular. Pop isminin tutunmasının nedeni televizyon, radyo, gazete gibi kitle iletişim araçlarına ilgiyi çekmesidir. Kitle iletişim araçları (televizyon, radyo, gazete, dergiler vb.) başka hiçbir sanat akımında görülmemiş bir katılımla, pop art adlı bu hareketin gelişmesine destek olmuştur (Lynton 289).

'Yeni Dada' denilmesi, yapılan işlere hazır malzemenin de taşınmış olmasından kaynaklanıyordu. Rauschenberg soyut dışavurumcu boya kullanımıyla oluşturduğu zeminlerin üzerine hazır malzemeler ekleyerek Dada'nın devamı gibi görünmüştür. Jasper Johns'un resimlerinde de bu tür kullanımlar kendini göstermektedir. "Johns'un işlerinin çoğu bira şişesi, bayrak, hedef tahtası, rakam ya da harf gibi, kendinden önce başkaları tarafından yaratılmış şeylerin yeniden üretimidir. Johns, bu sanat dışı, hazır biçimleri almış ve onları sanat dünyasına sokmuştur. Dolayısıyla Johns'un bu tavrının, Duchamp'tan kaynaklandığı ortadadır; ondan farkıysa resim ve heykel yapmaya inanması, en azından aralıksız sürdürmesidir" (Yılmaz 185).

Andy Warhol tüketim nesnelerini resimlerine taşımış olmasını Dadayla ilişkilendirdiklerinde şöyle diyor: "Dadaya ilk rastladığımda ona değer verdim ve 
oldukça iyi olduğunu düşündüm; ama aslında benimle bir ilgisi yoktu. Sanatım evrimleşmeye başladığında Dadanın benimle ilgili bir şeyler içerebileceğini fark ettim ki, bilinçli bir şeyden çok, bir sürpriz gibiydi bu...'(Y Ylmaz 161).

Dada'da Duchamp la birlikte görülen, değerli olanın bir şey olduğunu düşünmek olduğudur. Hazır nesne olan ve mekanik bir forma sahip olan pisuarı (1917) sergilediğinde çok tepki almıştı. Amaçladığı şey sanatın kutsallığını yıkmaktır. "Andy Warhol yaklaşık 40 yıl sonra ünlü kişilerin portrelerini yüzlerce kez çoğaltırken, insan imajını da mekanik bir imaj haline dönüştürmüştür. Bu özellik Duchamp'da bile yoktu” (Şahiner 35).

Duchamp'ın kullandığı nesneler tamamen makine estetiği taşıyan biçimlerdir. Warhol'un nesneleri ise "Hazır bulunmuş obje gerçekten olabileceğin, kutsallıktan ve ruhsallıktan en uzak nesnesidir. Bir brillo kutusudur” (Şahiner 36).

Warhol'un çalışmaları ve stratejileri mekanizasyon teknikleri gerçeğine uzanır. Bu mekanizasyon, Duchamp tarafından onaylanmış ve 1960'ların başında Avrupa ve Amerika'da yerleşmiştir. Bu nedenle Warhol geleneksel tanımların sorgulayıcısı olarak isteminin ortaya çıkmasıyla çağdaşları için tüm zamanların başlıca öğretici sanatçılarından biri oldu. Amacı, sanat objesinin tekliğini (yegâneliğini) nasıl reddetmesi gerektiğiydi. Eleştirmenler Duchamp'ın fikirlerini Warhol'un eserlerinde belirtmek üzere şöyle dediler: "Eğer bir adam elli campbell çorba kutusu alır ve bunu tuvalin üzerine koyarsa bu bizi ilgilendiren retinal görüntü değildir. Bizi ilgilendiren Tuvalin üzerine elli campbell çorba kutusu konmak isteniyor kavramıdır'(Wagner 98). 1965'te Warhol'un üstüne de Duchamp'1 belirtmek, 1960'da Warhol'la alakalı olan ne ise onun işaretini vermekti: ortaya çıkan kavramsal paradigmanın onun sanatını asimile etme ihtimali bulunmaktaydı. (Sadece resim olarak değil aynı zamanda fikir olarak da) bir eleştiri olarak Warhol'un sanat anlayışının, bunun ortaya çıkışının 1968'lerin sonrasında, sanatın siyasallaşması ve eleştiri üzerine koşullu olduğu görülüyor (Wagner 98).

Pop sanatın önemli temsilcilerinden biri olan Rauschenberg, çalışmalarına dâhil ettiği kola kutuları, dolgu hayvanları, atık malzemeleri ile de pop art'ın habercisi olarak tanınır. John Cage'in de etkisiyle çöplerden fotoğraf ve baskıya kadar çok farklı teknik ve malzemeler ile resim, heykel ve happening düzenlemiştir. Soyut dişavurumculuğun 1950'li yıllarda gündemde olduğu sıralarda Rauschenberg, John Cage'in Zen budizmi felsefesinden etkilendiği gibi kompozisyonlarından da etkilenmiştir. Daha sonraki yıllarda, sadece beyaza ve kırmızıya boyadığı tuvaller dikkat çekicidir. Maddi sıkıntıları, çevresindeki atık malzemeleri kullanmasına sebep olmuştur. Malzemenin belirleyiciliği ya da kullanılıyor olması Avant-garde tavrını meydana getirmiştir. 
Rauschenberg, artık çok tanındık, çağdaş elektronik çağın iletişim dinamizmine, tepkiyle, belki yeni teknik ve estetik sınırları araştıran ilk sanatçıydı. Texas'ta bir sergi için yapılmış "rodeo yeri" adlı çalışmada, ilk çalışmalarında koruduğu önemli kontrast ve kolaj teknikleriyle 60'ların ipek baskı görseline dikkat çeken kombinasyonlarıyla birleştirmiştir. Burada ve orada aşama aşama dağınık çizgiler ve resimlenmiş lekeler, sanki pop sanat ve eylem resmi arasındaki boşlukta köprü kuran bir resmi anımsatır(Hunter 302).

"Amerikan Soyutlamacı Resmi, içine doğru patlayan (implosive) bir arayışın sonucu ise, pop sanat kapsayıcı ve gündelikleşmeye açık oluşan bir yanıtıdır" (Kahraman 268).

"Pop art sanatçılarının ilahlaştırdığı dünyadan, soyut dışavurumcular nefret ediyordu"(Danto 164). Kooning'de ise durumlar farklıydı. 1953 yllında kadınlar sergisini açtığında soyut dışavurumcular bu resimleri ihanet olarak görmüşlerdi. "Pop art ya da büyük bir bölümü ticari sanat (...) üzerine temelleniyordu. Bu rengârenk ilan görsellerinden sorumlu ticari sanatçılar da iyi gözlere sahipti. Willem de Kooning tabela ressamlığı yapmıştı; tabela ressamının özel donanımını güzel sanatların amacına uyacak biçimde dönüştürürken, tabela ressamı olarak başarı kazanmasını sağlamış olan gözü kullanmadığını varsaymak zordur" (Danto 122). Pop sanatçılardan günlük nesneleri bulup kullanırken bu gözü ya da bakış açısını kullanmıyorlardı diyebiliriz. Willem de Kooning soyut dışavurumcular tarafından suçlansa da Warhol ise kendisine "içerik ve heyecan" (Yılmaz 160) verdiğini söylemiştir.

Warhol için "pop art nesneleri sevmenin yoludur" (Şahiner 26) bunun açılımını yaptığında da pop art iki şeydir:

"Birincisi, o insanları şeyleri ve imajları övmek için bir yoldur. İkincisi bunların neye benzediğini ve ne olduğunu gösteren bir yöntemdir. Ve sonuçta tabii ki pop art bir sanattır ve uzun bir imaj geleneğinin ciddi bir şekilde tartışılmasıdır" (Şahiner 26).

\section{Makine Olarak Andy Warhol}

"Warhol geçmişi ya da geleceği olan bir kişi yerine, eşsiz kendine özel günümüzün bir şeyi olmak istiyordu" (Bergin 360). Kişilikten yoksunma çabası Warhol'un makineleşme yönünde gördüğü en büyük özelliklerden birisidir. Onun tarihi yadırgaması ve sadece bir "şey" olmak isteği aslında kendisinin dediği gibi bir derinliği olmayan sadece bir maske kıvamındaki güzellik isteğidir. Bir makine gibi, 
o sadece işi gören ve işi bittiğinde aynen geldiği gibi gitmek isteyen bir sanatçı görünümünü vermek istiyor.

İmgeye geçiş ile tüm imgelerin mutlak eşdeğerliliği şeklindeki iki evre arasına dramatik bir şey sokuyordu." Ben bir makineyim, ben bir hiçim” onun ilkesi bunu söylemekti (...) Warhol bunun radikal bir şey olduğunu düşünüyordu "Ben bir hiçim yine de işlev görüyorum" "Ben her düzeyde çalışırım: sanat, ticaret, reklam..." "Ben işlevselliğin kendisiyim (Baudrillard 58).

Warhol, resimlerindeki imgelerin aslında hiç bir anlamı olmadan, beynimizin beklemediği noktalarda yer bulmasını istiyor. Onun için imgeler anlamadan üretildiği zaman bir makinenin ürünü gibi sadece nesneler çıkıyor ve de yansımalar oluşturuyor. Bu imgeler ne bir kişilik ne de bir duygu içeriyor, sadece imge hiçbir anlam taşımadan nesneyi gösteriyor. Bu yönden bakıldığında, Warhol'un imgeleri makineleşmeyi anlatır. "İlk ve en önemlisi, bilinçli olmadan, imgenin orijinal kimliğini anlamadan sadece onu üretmesi ve çoğaltması bir makinenin hareketi gibidir" (Bergin 362). Makine yerine, makinenin kendisinin çıkardığı imgeleri temsil ediyor. Bu makine imgeleri, fütüristlerin düşündüğü gibi bir gelecek övgüsü yerine, sadece 20. yüzyılın hayatını anlatıyor.

Warhol'un resim şekilleri bilinçaltında yer buluyor. Ne bilinçli bir beyinde ne de entelektüel bir kavramda yeri var. Warhol yansitmadan görüyor ve anlamadan üretiyor. Bize sadece bir cisim veriyor daha fazlası değil. Warhol'un sanatı makinenin sanatı fakat bu makineleşmeyi övmek için değil yani fütüristlerin yaptığ gibi değil. Warhol'un işi bir beyan, müzik değil. Onun sanatı bir kişilik ve duygudan arınmış sadece imgeyle ilgili bir sanat. Bu sanat makinenin sanat, makineleşmeyle ilgili olan sanat değil. Makine, Warhol için yaşam şekli, 20. yüzyılın eşsiz temsilcisi (Bergin 361).

Andy Warhol'un kendi sanatını açıklaması şöyledir: “Amerika’ya tapıyorum... Benim resmim bugün Amerika'nın üzerine inşa edilmiş olduğu kişiliksiz, kaba ürünlerin ve sakınması olmayan maddi nesnelerin ifadesidir. Bizi ayakta tutan yararlı fakat dayanıksız simgelerin, alınıp satılan her şeyin yansıtılmasıdır. Sanat metadır ve meta olduğunu işaret eder” (Bürger 25,26).

Sanatçı, aktarımını oluştururken kendine sınırlar koymaması gerekir. 'Anlatım dilim bu, ben ele alışımı değiştiremem, ben buyum' diyen sanatçı 'ben' dediği şeyi sorgulamadan bir kere oluşmuş olanı sürdürmekten başka bir şey yapmamış olur. 'ben'i oluşturanların arasında bulunan zaman kavramını düşünmeden kendisini zamanın içinde tek noktada bulunan bir 'ben' olarak aktarır. Andy Warhol, bu durumu şöyle ifade etmektedir; “... Bir biçimin diğerinde daha iyi 
olduğunu nasıl söyleyebilirsiniz? Herhangi bir şeyden vazgeçtiğiniz hissine falan kapılmadan, gelecek hafta soyut dişavurumcu, pop sanatçı ya da gerçekçi olabilmelisiniz.” (Y1lmaz 154).

Bütün biçimlerin bir arada var olabileceği ve var olduğu bir kürenin, adıydı sanat. Sanatçı artık her şeyi deneyebilir, her şeyle oynayabilirdi. Ama amaç artık birilerine ya da bir şeylere karşı çıkmak değildi. Artık bir düşmandan, karşı çıkılacak bir sistemden söz etme olanağı yoktu... Sanat artık özgünlüğünü yitiriyordu. Sanat, kendisine gönderme yapa yapa sonunda kendisine dönmüştür. McLuhan'ın dediği gibi sanat artık bir 'mozaik' oluyordu. Tamamlandığında sadece kendi serüvenini anlatan bir mozaik... (Kahraman 30).

Makineleşme döngüsünü Warhol iki yöntemle oluşturuyor. Daha önce bahsedildiği gibi, imgenin anlamı ve kimliği bir tarafa atılarak, sanatçı bir makine gibi imgeyi çoğaltıyor. İkinci olarak, Warhol serigrafiyi resimlerinde ve heykellerinde kullanarak makineleşmeye daha da yaklaşıyor. Warhol için serigrafi elle boyamaktan daha basit ve de bir makine gibi. En dirençsiz iş, en çok hoşuna giden iş. Serigrafi ile Warhol'un asistanları da bu işleri aynı onun gibi çıkarabiliyorlardı ve de bu şekilde onun stüdyosu bir resim fabrikası gibi çalışıyor, bilinçli olmayan bir makine gibi resim üretmesini sağlıyordu (Bergin). Warhol'un portrelerine baktığımızda “Özellikle Marilyn Monroe ve Elizabeth Taylor'ın portrelerinde, Warhol makine kavramını açıkça ortaya koyuyor; insanlar makine ürünü ve ticari mülkiyet olarak simgeleniyor" (Bergin).

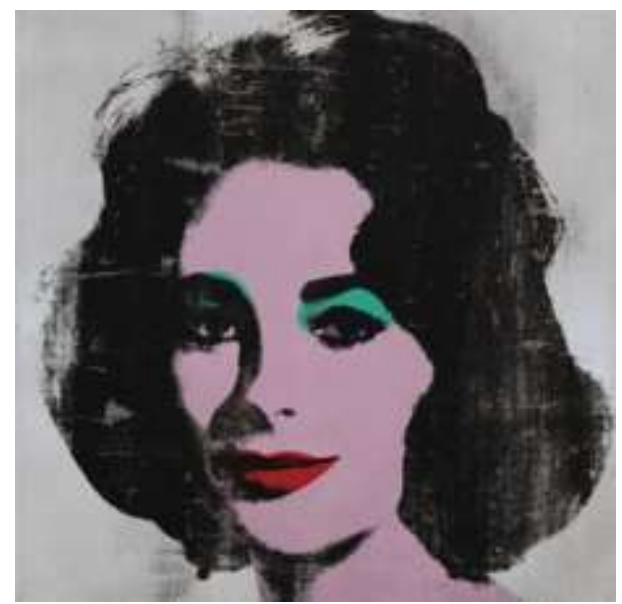

Resim 1: Andy Warhol, Liz, 1963, serigrafi, 106x106cm 
"Elizabeth Taylor, Campbell Çorbası gibi fakat değişik bir makine tarafından çıkarılan bir ticari mülkiyet. Bu tuvallerde onun sadece kamu imajı görünüyor, ya da John Rubloskwy dediği gibi onun maskesi görünüyor" (Bergin). Warhol'un insan portrelerinde bile makine kavramını oluşturmaya çalışması en açık Monroe ve Taylor portrelerinde görünüyor. Andy için bu portrelerdeki yüzler sadece maskelerden oluşuyor. Bu ünlü kişiler, artık bir alım verim değeri olan makine ürünü olup, ticari mülkiyeti simgeliyor. Bu portrelerde herhangi bir his ya da düşünce olmadan, imge kullanım değerinin çerçevesinde çiziliyor ve gösterime sunuluyor.

İpek baskı stili Warhol'un sanatında büyük bir yer taşıyor. İpek baskı ile birlikte çok zaman alan el çizimleri bir tarafa kalktı̆̆ 1 gibi, bundan sonra Warhol dışındaki bütün asistanları da aynen onun gibi resimler yapma olanağına sahip oldu. "Ellerimle resim yapmayı denedim, fakat baskının çok daha kolay olduğunu anladım. Bu yolda ben kendi objelerim üzerinde çalışmak zorunda değilim. Asistanlarımdan birisi ya da herhangi biri benim yaptığım gibi bu tasarımları üretebilir" (Honef 54)

...Warhol'un mekanik süreçlerin tüm otografik dokunuşla görünümüne rağmen yeni bir resimsel tekniğin ortaya çıkışıyla sonuçlandı: Warhol'un farklı miktarda boyayı serigrafi tekniğiyle yüzeye aktarmasıyla oluşturduğu tekrarları, baskı sırasında ipeğe uygulanan basınç sonucu kimi zaman elle yapılmış nadiren de ince bir işçilikle çözümlenmiş (perfection) bir görünüm sunuyordu (Şahiner 31).

Marilyn'i çalıştığı resimlerinin bir çoğu, kırık beyaz zemin üzerine siyahla, serigrafi tekniğiyle basılmıştır. Bu serinin en çarpıcı görsele sahip olanı, çok renkli zemin üzerine siyahla basılmış olanlardı. Genellikle turuncu zemin üzerine yüzünün renklendirilmiş haritasını çıkartırken önce saçlar için sarı bir alan, göz çevresi için mavi, dudaklar için kırmızı, yüz için ten rengi, yaka için yeşil renk kullanmıştır. Warhol biçimlendirdiği alanların bazılarını olduğundan geniş alanlarda, taşırmalar yaparak oluşturmuştur. Kırmızı dudaklar ve göz çevresi daha geniş şekilde boyanmış taşan makyaj gibidir. Serigrafi tekniğini bildiği halde, kayma olmaması için kullanılan köşe işaretlerini, kalıpları üst üste basarken kullanmamıştır. Her karesi bir diğerinden farklı olan film şeridinin etkisini hissettirmek için aynı görüntüyü peş peşe basarak oluşturmuştur. Gold Marilyn Monroe resminde Marilyn'in eşsizliğini hatırlatmak için metalik sarı zemin üzerine, merkeze yerleştirdiği Marilyn diğer peş peşe basılmış çalışmalarından farklıdır (Bourdon 124-126).

Warhol'un resimlerinde her imge yüzeydedir. Seri imgelerinde aynı imgeleri yapmak farklı imgeleri yapmakla aynıdır. Aynı olanın tekrarı, farklı olanın tekrarıyla aynıdır. Gilles Deleuze, kitabı 'Farklılık ve Tekrar'da, farklılık, farklılaşma, tekrar 
görüşlerini yansıtır. Aynı olanın tekrarı vardır. "Kavramsız farklılık", aynı kavrama sahip olan, tıpatıp aynı elementlerin karşılaştı̆̆ı yerdedir. Warhol'un Marilyn portre serileri Hepsi Marilyn konsepti altında anlaşılır. Bu açıdan, bireysel portrelerin farklılıkları kazaradır (tesadüfî). Fakat Deleuze için bu diğer tekrar, "gizli özne, gerçek öznenin tekrarıdır”. Warhol'un seri imgelerinde, tekrar edilen Marilyn örneği farklılığın tekrarıdır. Warhol, tesadüfî oluşacak bu farklılıkları oluşturabilir, fakat sonucu tahmin etmesinin imkânı yoktur. Kazara olan hareketin izi, her imgeyi tek (yegâne) yapar. Bu yüzden Warhol'un imgelerindeki farklılıklar farklılığın inşa edilmesi değil, farklılığı inşa işidir (Dyer 15-18)

Warhol 1949 yılında sanat eğitimini, Carnegie teknoloji enstitüsünde tamamladıktan sonra New York'taki birçok dergi için çizimler yaptı. O, çizimlerini ve yaptığı işi şöyle anlatıyor: "Benden istenileni yapıyordum ve o işten para kazanıyordum. Örneğin 'bir ayakkabı çiz' dediklerinde, çiziyordum: düzeltmemi istediklerinde de düzeltiyordum. (...) o zaman bir buluş yapmak zorundaydım, ama şimdi değilim. Bütün 'düzeltmelerden' sonra o reklam çizimleri duyarlı olmalıydı, hepsinin bir biçemi olmalıydı.” (Yılmaz 191)

...Patronları memnun etmek için bir buluş yapması şarttı. Ama işin garibi mecburen yaptığı o buluşlar- tasarımlar - sanat değildi, ama öte yandan, buluş yapma endişesi gütmeden keyfine göre yaptığ 1 şeylerse sanattı - işte bunu anlayamıyordu! Evet, diğerleri normal piyasa, bunlarsa sanat piyasası için üretilen şeylerdi, ancak her iki piyasada aslında aynı piyasanın farklı yüzleriydi. Ayakkabı tasarlarken de bilmiyordu müşterileri, resim yaparken de. Ancak her iki cins şeyleri muhtemel müşterileri hazırdı aslında. Onların kim olduklarını ayakkabı ya da resim sanatçıları biliyordu ve önemli olan buydu. Önemli olan, iyi bir pazarlama stratejisiyle, sıradan şeyleri olağan üstü şeylermiş gibi sunmak ve müşteriyi ikna etmekti (Y1lmaz 191).

Amerikan toplumunun, beğeni ve ilgilerine dayanan bakış açısıyla, sanat yüksek kültürden uzaklaşırken, ilgi çekici olan Pop Sanatı beğeni listelerine almış oluyorlardı. Warhol için bu ilgi, sanatının paraya dönüşebilmesi anlamına geliyordu ve yaptığı resimlerden para kazanmayı şu şekilde açıklıyor:

İş resmi, resimden sonra gelen adımdır. İş ressamı olarak başladım ben ve iş ressamı olarak bitirmek istiyorum. "Resim" ya da her ne ad veriliyorsa, böyle şeyler yaptıktan sonra, iş resmine geçtim. Bir sanat iş adamı ya da bir iş ressamı olmak istiyorum. İşte iyi olmak en büyüleyici sanat türüdür. Hippiler iş düşüncesini aşağılar, "para kötüdür", "çalışmak kötüdür" derlerdi, fakat para kazanmak sanattır, çalışmak sanattır, iyi iş ise en iyi sanattır. (Yapı Kredi, 2001, s. 90) 
Kuspit, Warhol'un sanat-para ilişkisini şöyle açıklıyor: İkisinin birbiri yerine kullanılır olması, ikisinde de yozlaşmış bir şeyler olduğunu göstermektedir. Farklı alanlara aitlerdir. Warhol, parayla sanatı birbirlerinin değerini artırmak için kullanmak istediyse de onlara birbirinin değerini vermekle değersizleştirmiştir. Warhol' un "resim ya da her ne ad veriliyorsa", biçiminde ki ifadesi çok şey ifade etmektedir. Sanatın neden önemli olduğu, ne anlama geldiği, ne olduğu artık açık değildir. Warhol için paranın ne anlam ifade ettiği ise gayet açıktır. Sanatı belirleyecek olan paradır, sanat ticaridir; bu da sanatın gücünden çok ticaretin gücüne ilişkin ipuçları verir. Sanatın paha biçilemez bir içsel değeri varsa ve paranın değeri değişim değeriyse birliktelikleri sapıkçadır. Ama bu durum ChasseguetSmirgel' in savunduğu gibi " genel anlamda sapıkça olan şey... Yasayı tersine çevirerek bilinçli ya da bilinçsiz bir biçimde onunla alay etme girişiminde bulunuyorsa" Warhol'da sanatı parayla dönüştürerek sanatla alay etme girişiminde bulunmaktadır. Warhol sanata parasal değer verir, para başka şeyle değiştirilmediği sürece değersizdir. Sanat, toplumsal ve ekonomik itibar kazanmak adına manevi itibarını kaybeder. Warhol'un sanatçısı işadamıdır. Sanat da satılık metadır ve modası geçecek biçimde üretilme özelliğine de sahiptir. Onun sanatı gerçek paranın yerine geçebilecek sahte sanattı (2006, s. 161-168).

Ticari sanatçı olarak, Warhol reklam endüstrisi için çalıştı. Bu endüstride, sosyal beklentileri motive eden güç, değişim-değeri olduğundan ve fotoğraf, üretimi artırdığından dolayı, Warhol bu yönde çalıştı ve sanatını değişim-değerinde sattı. Warhol sadece resim makinesi değil, ayrıca film makinesi, baskı makinesi, kayıt makinesi ve de sanat pazarının bankamatiği idi. Bu makine olma isteği onun politik ekonomi ile tekel kapitalizminin bağlaştığı yerde oluşturduğu değerlerde görünüyor. "Factory"de, Warhol üretimi artırmak için makineler almadı ve dünyayı ipek baskılarıyla doldurmadı; ona göre, kendisi bir makine idi ya da öyle olmak istiyordu. Psikolojik anlamda düşünülürse, Warhol herhangi bir istekten ve ölüm korkusundan kendini arındırmak istiyordu. (Duve 10-12)

İpek baskı metodu, Warhol'un resimleri üstünde büyük bir değişim oluşturdu. $\mathrm{Bu}$ yeni metotla birlikte Warhol, herhangi bir insan eliyle çizilmiş nesnelerden kurtularak, resimlerindeki bütün öznelliklerden ve de bu yüzden soyut dışavurumdan ayrılmıştır. Ayrıca, bu makineleşmiş metot kendisinin analitik karakterini sanatında daha da öne çıkarmıştır. (Honef)

Warhol'un 'ticari dönemi' onun en çok makineleşmeye yaklaştı̆̆ dönem olarak görünüyor. Bu dönemde yiyecek büyük bir önem taşıyor. İnsan, tarihte ilk defa açlığını, insan eli dokunmamış yiyeceklerle giderebiliyordu. Warhol bu değişimin farkındaydı ve de, özellikle Campbell Çorbası tuvallerinde, bize 
makinenin hayatımızda önemini gösteren imgeleri verdi - insan eli dokunmamış sanat (Bergin).

20. yüzyılda oluşan makineleşmenin getirdiği değişikliklerde, yiyecek sektöründe de kendine yer buldu. Campbell çorbasının hiç bir insan eli değmeden yapılıp, perakende edilişi, aslında Warhol'un resimlerindeki makineleşmenin aynısıdır. Warhol da, Campbell Çorbasını yapan makine gibi, sanatında insan elini kaldırarak, makine olmak isteğiyle imgelerini basıp, çoğaltıyordu.

Pop sanatında imgeler, gerçek konularla ilişkilidir. Oluşturulan biçimler, var olanın temsilidir. "Temsilin tüm biçimleri (gerçeklik dâhil) ancak kendine gönderme yapan kodlar olabilir" (Foster 162).

Warhol, ölüm imgelerini gösteren resimlerini, o dönemde gazetelerde çıkmış intihar ve araba kazası fotoğraflarını büyütüp, çoğaltıp yan yana koyarak gösterime sunmuştur. Fotoğraflarda kullanılan siyah beyaz rengini aynı tutarak güçlü bir görsel deneyim oluşturuyor. En önemli düşünce, araba kazalarını 'yan yana' tekniğini kullanarak gösteriyor. $\mathrm{Bu}$ otomobil ve ölüm teması, fazla irdelemeden kendi düşüncelerini resimle bağlaştırmaya çalıştıranlar için tehlikeli bir ortam oluşturuyor. Makineyi ölüme yol açan bir faktör olarak görenler, basit yollardan çıkış yolu ararlar (...) Bu imgenin kaynağı bir gazete haberi fotoğrafi ve bu fotoğraf herhangi bir değer yargisı olmayan ve de ayrıca makine olan matbaa tarafından üretilmiştir. Bu soyutlaşma içinde sanatçı Warhol, sadece imgeyi alıyor; O'nun ölümle hiç bir ilişkisi yok ve sadece verilen imgeye reaksiyon verebiliyor, gerçek ölüme değil. İmgenin kaynağı ile birlikte, tekrarlama tekniğiyle, herhangi bir değer yargısı olmadığını gözlemciye gösteriyor. $\mathrm{Bu}$ tekrarlama, imgeyi önemsizleştiriyor. Bu bağlamda, ölüm imgesi, yirminci yüzylldaki makinenin bir başka ürünü. Ölüm simgesi ne iyi ne de kötü; o sadece bir imge (Bergin). 


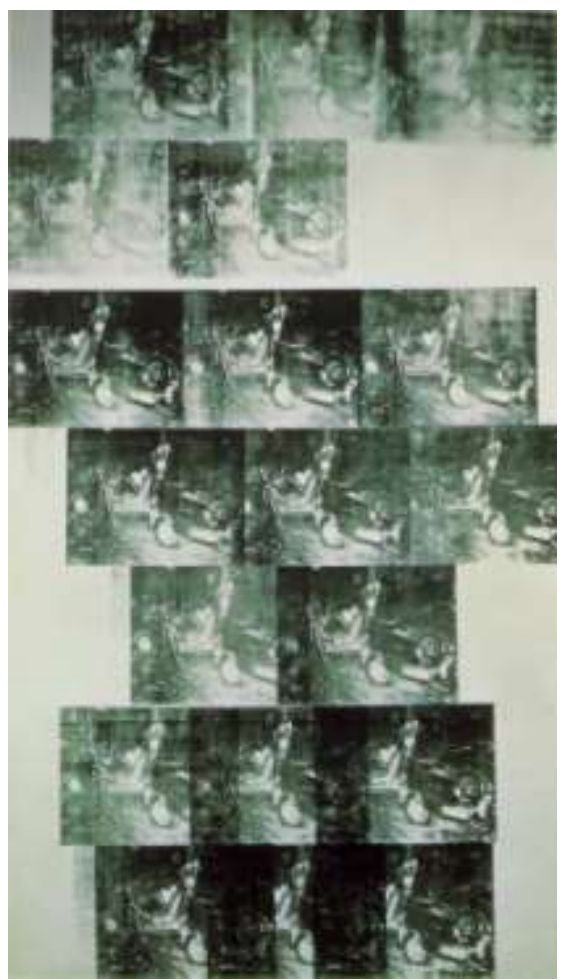

Resim 2: Andy Warhol, Beyaz Araba Kazası 19 defa, 1963, Serigrafi, 368x211.5cm

Hal Foster ise “Amerika'da ölüm imgeleri göndergesel ve simülakral, bağlantılı ve bağlantısız, etkileyici ve etkisiz, eleştirel ve kayıtsız olarak yorumlanabilir mi?" (165) sorusunu sorduktan sonra, yöntem olarak travmatik gerçeklik açısından ele almaktadır. Travmatik gerçeklik kavramını aydınlatmanın yolu olarak da bir önceki kısımda açıklamaya çalışıldığı Warhol'un 'makine olmak istiyorum' sloganının devamı olduğunu ifade eder. Warhol'un resimlerindeki tekrarlarla anlamın güçsüzleşmesini, izleyenin onu doğal karşılamasını sağlar. Kendi ifadesiyle;

Tüyler ürpertici bir fotoğrafı tekrar tekrar gördüğünüzde artık hiçbir etkisi olmaz" bu, en azından Freud'un algıladığı biçimiyle, tekrarın işlevlerinden biridir. Travmatik bir olayı ruhsal bir sisteme, simgesel bir düzene katmak için (eylemlerde, rüyalarda, imgelerde) tekrarlamak. Fakat Warhol un tekrarları bu anlamda yenileyici 
değildir, onlar travmayı yenmeyle de ilgili değildir. (...) Warhol tekrarları, travmatik etkiyi sadece yeniden üretmez; aynı zamanda üretir. Bu tekrarlarda bir şekilde birçok çelişkili durum aynı anda oluşur. Örneğin travmatik önemin hem geçiştirilmesi, travmatik etkiye hem karşı durulması hem gösterilmesi gibi (Foster 167).

Lacan, gerçeği travma terimiyle şu şekilde açıklar: “...Travmatik olanı gerçekle ıskalanmış bir karşılaşma olarak tanımlar. Gerçek ıskalanmış olduğundan temsil edilemez; sadece tekrar edilebilir, hatta tekrar edilmelidir (...) tekrar yeniden üretim değildir''der. (...) Warhol'da tekrar, (göndergenin) temsil veya (saf bir imgenin, bağlantısız bir göstergenin) taklit anlamında bir yeniden üretim değildir. Tekrarlama daha çok travmatik olarak algılanan gerçeğin sahnelenmesi sağlar. Fakat bu ihtiyaç aynı zamanda gerçeği de gösterir ve bu noktada gerçek tekrarlama sahnesi yırtar" (Foster 167,168).

$\mathrm{Bu}$ yırtılmayı Berthes, punctum olarak adlandırır. Berthes "Bu öğe sahnede yükselir, bir ok gibi dışarı firlar ve bana saplanır"der (Foster 168). İzleyenin resmin odağıyla buluşması, resme yaklaşmasıdır. Ok bize atılan değildir, bizi bulan ve tutandır." Punctumun konumu hakkındaki bu karışıklık, özne ve nesnenin, içeri ve dışarının karışıklığıdır. $\mathrm{Bu}$, travmanın bir yönüdür; aslında travmatik olan bu karışıklıktır" (Foster 170) belirliyor:

Warhol'un ‘Amerika'da Ölüm’ Resimlerinde Punctumu Hal Foster şöyle

Yanan Beyaz Araba III resminde yoldan geçen kişinin kayıtsızlığında bir punctum vardır.(...) Telefon direğinin delip geçtiği bir kaza kurbanına yönelik bir kayıtsızlık yeterince kötüdür. Fakat onun tekrarı rahatsız edicidir ve bu Warhol'da punctumun genel işleyişini ifade eder. Burada puctum içerikten çok teknik üzerinden, özellikle, ipek baskı işleminin 'yüzen şimşekleriyle' kayan ve çizgilenen, ağaran ve üzerinde boşluklar oluşan, tekrarlanan ve renklendirilen görüntülerle çalışır. (...) ambulans felaketinde punctum, resmin üst kısmındaki yığılmış kadın görüntüsünde değil; alt kısmında kadının kafasının olduğu yerdeki yüzeyi silen baskı hatası yırtıkta ortaya çıkar. Her iki örnekte de Warhol'da punctum, detaylardan çok görüntülerin tekrarlanan 'hareket edişine' bağlıdır (Foster 170).

Warhol'un çiçek resimleri 20. yüzyıldaki makine kavramına daha farklı bir ifade veriyor. Warhol'un çiçekleri tarla çiçeklerinden çok şehir çiçekleri; yassı ve gerçekçi olmayan şekilleriyle, bize plastik yapay ve günümüzde çok yaygın olan çiçekleri andırıyor. Warhol çiçekleri, yirminci yüzyılın makine çiçekleri. Onlar tamamen çiçek kavramından sıyrılmış sadece çiçek imgesi veren duvar kâğıtlarında 
ve de modern resimlerde bir cisim olarak yer buluyor (Bergin 361). Çiçeklerin yassı ve yaşamsız çizimleri, makineleşmenin imgeleri doğadan ayırıp kendi dünyasında oluşturduğu kavramalarla buluşturuyor. Çiçekler artik tarlalarda değil de duvar kâğıtlarında ve makineleşmiş tuvallerde yerlerini alıyorlar. $\mathrm{Bu}$ değişimde, çiçek imgesi onu doğada çiçek yapan bütün özelliklerinden sıyrılıp, bir makine nesnesine indirgiyor.

"Pop" sanatçısı Warhol çağdaş sanatın yeni ilerleyişini gördü. Zamanın, toplumun eğilimlerini ve beklentilerini takip etti. Farklı şekilde göstermesini bildi. "Sanat yaşamına bakıldığında, Warhol acılar çeken bir deha olmadı, bütün medya araçlarını kendi isteğine göre kullanan bir tür profesyonel sanat menajeri oldu. Yöntemi modern tüketici sanayi toplumunun içindeki gizli mekanizmaları ortaya çıkarttı, derinlemesine çözümlemelerde görülebilecek bağlantıları gösterdi ....) $\mathrm{Bu}$ bakış açısından sonra sanat çok daha farklı bir yöne yürümeye başladı." (Yapı Kredi 46).

\section{SONUÇ}

Sonuç olarak Warhol'un hayatı açık olarak toplumdur. Sanatı kendi tarafından yaratılmıştır ve özgürlük Warhol'un uygulamalarının temel özelliğidir. Warhol birbirinden tamamen farklı toplum içinde birleştirici bir unsurdur ve bu toplumda kimse kendi tesadüfî faaliyetlerinin sonucunu belirleyemez. Onun tepkisi otomatiktir. Warhol aslında bir makinedir. Fakat ironik bir makinedir; çünkü o özgür ve spontandır. Warhol'un konularını anlamak için spontaneity (kendinden oluş) açısından, onun ne çeşit bir kendinden oluş olduğuna bakmak gerekir. Kendinden oluş, hem şans hem de yeniliğin belirlenemez özgür patlamasıdır. Şans en az iki sıradan zincirin umulmadık şekilde kesişmesidir.. Kendi ismi altında Warhol'un sanatı, çok çeşitli değişik sanat yapımları barındırır (Dyer, 2004, s. 19-20). 


\section{KAYNAKÇA}

Baudrillard, Jean. Sanat Komplosu. İstanbul: İletişim Yayınları, 2010.

Bergin, Paul. «Andy Warhol: The Artist as Machine.» Art JournalVol. 26, No. 4, (1967): 359-363.

Bourdon, David. Warhol. New York: A Times Mirror Company, 1991.

Bürger, Peter. Avangard Kuramı. İstanbul: İletişim Yayınları, 2009.

Danto, Arthur C. Sanatın Sonundan Sonra. İstanbul: Ayrıntı Yayınları, 2010.

Duve, Thierry and Rosalind Krauss. «Andy Warhol or The Machine Perfected.» The MIT Press (1988): 3-14.

Dyer, Jennifer. «The Metaphysics of the Mundane: Understanding Andy Warhol's Serial Imagery.» Artibus et Historiae Vol. 25, No. 49 (2004): 33-47.

Foster, Hal. Gerçeğin Geri Dönüşü. İstanbul: Ayrıntı Yayınları, 2009. Verlag, 1990.

Honef, Kalus. Andy Warhol 1928-1987 Commerce into Art. Köln: Benedict Taschen

Hunter, Sam And John Jacobus. Modern Art: Painting, Sculpture, Architecture. New Jersey: Englewood Cliffs, 1983.

Kahraman, Hasan Bülent. Sanatsal Gerçeklikler, Olgular ve Öteleri. İstanbul: Agora Kitaplığ $1,2005$.

Lynton, Norbert. Modern Sanatın Öyküsü. İstanbul: Remzi Kitabevi, 1989.

Şahiner, Rıfat. Sanatta Postmodern Kırılmalar ya da modernin yapıbozumu. İstanbul: Yeni İnsan Yayınevi, 2008.

Wagner, Anne M. «Warhol Paints History, or Race in America.» Representations No. 55, Special Issue: Race and Representation: Affirmative Action (1996): 98-119 .

Yapı Kredi. Sanatı Ve Yaşamıyla Andy Warhol. İstanbul: Yapı Kredi Kültür Sanat Yayıncılık, 2001. 2005 .

Y1lmaz, Mehmet. Modernizmden Postmodernizme Sanat. Ankara: Ütopya yayınevi,

—. Sanatçıları Okumak Ya Da Postmodern Söyleşiler. Ankara: Ütopya Yayınevi, 2009. 